\title{
Determination of Resistance in Winter Wheat Genotypes to the Dryland Root Rots Caused by Fusarium culmorum in Turkey
}

\author{
Gul Erginbas Orakci ${ }^{\star} \quad$ Alexey Morgounov Abdelfattah Adnan Dababat \\ Global Wheat Program-CIMMYT (International Maize and Wheat Improvement Centre), Ankara, Turkey
}

Received: 12.04.2018 Accepted: 11.06.2018

\begin{abstract}
Keywords:
Fusarium, resistance, root rot, wheat

Abstract. The dryland root rot (foot/crown) caused by Fusarium spp. attacks cereals especially wheat and causes severe yield loss by reducing both grain quantity and quality. Among those Fusarium species attacking wheat crop is the Fusarium culmorum species which has been reported as the main crown rot causal agent in Turkey. Unfortunately, up-to-date, there is only some wheat genotypes with partial resistant to Fusarium spp. Therefore, this study was carried out to find new sources of resistance in diverse wheat genotypes to limit the damage caused by Fusarium disease. In this study, a total of 141 genotypes and breeding lines were obtained from 19 different countries, provided via the International Winter Wheat Improvement Program (IWWIP) and screened for their resistance reactions to a local isolate of Fusarium culmorum under three different environmental conditions (growth room, greenhouse and field) in Turkey in 2012. The best performed genotypes in terms of resistant were then rescreened in 2013 for data validation. Out of the 141 phenotyped wheat genotypes, 17 genotypes (12 $\%$ ) ranked as moderately resistant (MR) at seedling and/or adult growth stage. The genotypes from

*Corresponding author gul_erginbas@hotmail.com

Mexico seemed to have adult plant resistant rather than seedling resistance which was higher in the USA genotypes. Winter bread wheats PATWIN YR5 and TAST/SPRW//ZAR/5/YUANDONG 3/4/PPB8$68 / C H R C / 3 / P Y N / / T A M 101 / A M I G O$ which possess high level of resistance seem promising for breeding for foot rot.
\end{abstract}

\section{Kışlık Buğday Genotiplerinin Türkiye' de Kök Çürüklüğü Etmeni Fusarium culmorum'a Karşı Dayanıklıığı'nın Belirlenmesi}

Anahtar kelimeler:

Fusarium, dayanıklılık, kök çürüklüğü, buğday

\begin{abstract}
Özet. Kuru alan kök (kökboğazı/dip) çürüklükleri'ne neden olan Fusarium türleri tahıllara özellikle buğdaya zarar vermekte, tane sayı ve kalitesini azaltarak önemli verim kaybına neden olmaktadır. Türkiye'de kök çürüklüğü hastalık etmeni Fusarium türleri içinde buğday bitkisine zarar veren başlıca etmen olarak rapor edilen tür Fusarium culmorum'dur. Maalesef, günümüze kadar Fusarium türlerine karşı sadece birkaç kısmi dayanıklı buğday genotipi bulunmuştur. Bu nedenle, bu çalışma Fusarium hastalığının neden olduğu zararı sınırlandırmak amacıyla çeşitli buğday genotiplerinde yeni dayanıklılık kaynaklarının bulunması amacıyla yürütülmüştür. Çalışmada, Uluslararası Kışlık Buğday Geliştirme Programı (IWWIP) aracılığıyla 19 farklı Ülke'den toplam 141 ıslah materyali (hat ve çeşit) sağlanmıştır ve Türkiye'de 3 farklı ortamda (büyütme odası,sera, tarla) yerel izolat Fusarium culmorum'a karşı dayanıkıııklarının belirlenmesi amacıyla 2012 yılında test edilmiştir. Dayanıklıık bakımından en iyi performansı gösteren genotipler verilerin doğrulanması amacıyla 2013 yılında tekrar test edilmiştir. Fenotiplendirme yapılan 141 genotip içinden toplam materyalin \%12' lik kısmını oluşturan 17 genotip fide ve/veya yetişkin dönemde orta dayanıklı olarak gruplandırılmıştır. Meksika kaynaklı genotipler, fide dayanıklıığı daha fazla gösteren Amerika kaynaklı genotiplerin aksine yetişkin dönem dayanıklılı̆ı göstermiş̧ir. Yüksek dayanıklılık gösteren kışlık buğdaylar PATWIN YR5 ve TAST/SPRW//ZAR/5/YUANDONG 3/4/PPB8-68/CHRC/3/PYN//TAM101/AMIGO kök çürüklüğü' ne karşı Islahta ümitvar olarak görülmektedir.
\end{abstract}


Erginbaş Orakci et al., Determination of Resistance in Winter Wheat Genotypes to The Dryland Root Rots caused by Fusarium culmorum in Turkey

\section{INTRODUCTION}

Wheat is grown on $20 \%$ of the cultivated land area of the world and is a main food resource for $40 \%$ of the world's population (Braun et al., 2010). In 2016, an estimated of 742 million tons of wheat (Triticum aestivum L.) was produced from 223 million ha (FAO 2018). In 2050, the world's population is expected to reach 9 billion, thus it is estimated that cereal production needs to increase by $50 \%$ by 2030 (Alexandratos and Bruinsma 2012). Turkey is one of the 10 largest wheat producers in the world with an average grain yield estimate of 2.5 tonnes - ha and varying wheat production between 16 and 21 million tonnes (Braun et al., 2001). So far the wheat production is suffering substantial losses of biotic and abiotic stress factors. Among the biotic stress factors; Fusarium species causing foot, crown and root rots occur in winter cereals worlwide virtually wherever cereal-based farming system predominates (Burgess et al., 2001). The disease can be caused primarily by Fusarium culmorum, F. pseudograminearum (formerly $F$. graminearum group 1), and $F$. graminearum (formerly $F$. graminearum group 2). Those three species have been reported to be associated with wheat and cause significant yield damage in West Asia and North Africa (Egypt, Tunisia, Morocco, Algeria), USA, Canada, Australia, Turkey (Smiley 2005; Tunali 2008; Chakraborty 2010). Fusarium root rot mainly caused by F. culmorum is characterized by a decay of the crown and lower stem tissue, resulting in scattered white heads with shriveled or no grain under disease favorable conditions and ultimately in the reduction of grain quality and quantity (Cook 1980). Yield loss due to these pathogens have been reported and reached up to $35 \%$ in winter wheat in Pacific Northwest (PNW) of America (Smiley 2005), 25-58\% in Australia while the disease can inflict yield losses of up to $89 \%$ (Klein 1991; Chakraborty et al., 2010) and up to $49 \%$ in Tunisia (Chekali 2016). In Turkey, losses have been reported in winter wheat and reached up to $43 \%$ (Hekimhan et al., 2004), 54\% in durum wheat in Central Anatolian Plateau (CAP) (Bagci et al., 2001). Aktaş et al. (1999) reported disease intensity of $36 \%$ in winter cereals as a result of root and crown rots. The CAP coveres 10 million hectares of cultivated land of which winter wheat is considered the main cultivated crop with an annual precipitation between $250-500 \mathrm{~mm}$ (Benli et al., 2007). About $90 \%$ of wheat areas in Turkey are cultivated under rainfed or supplementary irrigation conditions, where drought stress is common (Braun et al., 2001) and considered a favorable environment for the dryland foot rot. Fusarium culmorum has been reported as the prevelant species causing foot rot in Turkey (Akgül 2008; Bentley 2006; Hekimhan et al., 2004; 2010; Nicol et al., 2004; Tunali et al., 2008, Shikur 2017). Using resistant crops of high yielding potential is the most efficient and economical way to increase wheat productivity and manage soil borne pathogens especially in dryland fields. However, varieties with high level of resistance are still not available (Li et al., 2012). Only few sources with partial resistance which have been identified and used for molecular mapping studies such as Kukri (Wallwork et al., 2004), 2-49 (Collard et al., 2005), W21MMT20 (Bovill et al., 2006), CSCR6 (Ma et al., 2009), Ernie (Li et al., 2010). Based on the foregoing, crop rotation with non-host crop or cultivars is still one of the most recommended methods to reduce the damage caused by Fusarium species (Burgess et al., 2012) though in rainfed wheat production systems where cereal monoculture is practiced extensively as it is the case in Turkey, rotation offers limited option to control root rot diseases ( $F$. culmorum). Therefore, the main objective of this study was to screen diverse winter wheat genotypes to find new sources of resistance against the dryland $F$. culmorum based on multiple screening environments which will ultimately widen the genetic pool by using those sources in the breeding programs.

\section{MATERIAL AND METHOD}

\section{Plant Genetic Resources}

A set of 141 winter wheat genotypes provided by the International Winter Wheat Improvement Program (IWWIP) representing 19 different countries of a broad geographical spectrum along with the standard 6 breedinglines/varieties known for their resistant reaction to the dryland root rot caused by F. culmorum were evaluated in this study (Table 1).

\section{Fusarium Inoculum}

A local Fusarium species isolated from naturally infested field in Kırsehir, Turkey (39 39' 709" N, $32^{\circ}$ $\left.37^{\prime} 14^{\prime \prime} \mathrm{E}\right)$, molecularly identified as F. culmorum according to Nicholson et al. (1998) was used in all tests. This isolate was selected and used in this study based on its high virulence (88\%) against wheat genotype. A monosporic isolate of $F$. culmorum was cultured on Synthetic Nutrient Agar (SNA) medium $\left(\mathrm{KH}_{2} \mathrm{PO}_{4} 1 \mathrm{~g}, \mathrm{KNO}_{3} 1 \mathrm{~g}, \mathrm{MgSO}_{4} .7 \mathrm{H}_{2} \mathrm{O} 0.5 \mathrm{~g}, \mathrm{KCl} 0.5 \mathrm{~g}\right.$, Glucose $0.2 \mathrm{~g}$, Sucrose $0.2 \mathrm{~g}$, Agar $20 \mathrm{~g}, 1000 \mathrm{ml}$ distilled water) at $23{ }^{\circ} \mathrm{C}$ for 10 days. Propylene bags $(48 \mathrm{~cm} \times 20 \mathrm{~cm})$ (Unicorn, Amsterdam, Netherlands) were quarter filled with wheat bran, autoclaved at 121 ${ }^{\circ} \mathrm{C}$ for $20 \mathrm{~min}$ for three consecutive days. One week 
Erginbaş Orakci et al., Determination of Resistance in Winter Wheat Genotypes to The Dryland Root Rots caused by Fusarium culmorum in Turkey

Table 1. Breedinglines/varieties and their resistant reaction to the root rot caused by Fusarium culmorum used at the soil borne disease at CIMMYT-Turkey program.

Çizelge 1. CIMMYT-Türkiye Toprak Kökenli Hastalıklar programında kullanılan bu kontrol hatları/çeşitleri ve Fusarium culmorum' un sebep olduğu kuru alan kök çürüklüğü'ne karşı dayanıklılık bakımından reaksiyonları.

\begin{tabular}{llll}
\hline Wheat Genotype & Resistance Rating & Type & Source \\
\hline Altay 2000 & MR & WW & Turkey \\
Sonmez & MR & WW & Turkey \\
$\mathbf{2 - 4 9}$ & MR & SW & Australia \\
Sunco & MR-MS & SW & Australia \\
Seri 82 & S & FAC & Mexico \\
Kiziltan 91 & HS & FAC & Turkey \\
\hline
\end{tabular}

Abbreviations stand for: MR= Moderately Resistant, MS= Moderately Susceptible, $\mathrm{S}=$ Susceptible, MS= Moderately Susceptible, $\mathrm{HS}=\mathrm{Highly}$ Susceptible, WW= Winter Wheat, SW= Spring Wheat, FAC = Facultative.

later, $15 \mathrm{ml}$ of sterilised water consisting of mycellium from the monosporic culture was transferred into each bag and left for 2 to 3 weeks at $23{ }^{\circ} \mathrm{C}$ to enhance sporulation and thereafter used as source of inoculum in this study.

\section{Seedling Resistance Screening (Growth room)}

Wheat seeds were placed onto a moist blotting paper in sterilled petri dishes and left for 3 days at 23 ${ }^{\circ} \mathrm{C}$ to enhance germination. Seeds were left till $3 \mathrm{~cm}$ long radicules roots were formed. A single pregerminated seed was sown in a plastic tube (Stuewe and Sons, Corvallis, OR) measuring $(16 \mathrm{~cm}$ height $\times 2.5 \mathrm{~cm}$ diam.) containing potting mixture of sterilised sand, field soil, and organic matter (50:40:10, $\mathrm{v} / \mathrm{v} / \mathrm{v})$. Sand and field soils were sterilised at $110^{\circ} \mathrm{C}$ for $2 \mathrm{~h}$ and organic fertilizer was sterilized at $70^{\circ} \mathrm{C}$ for $5 \mathrm{~h}$. Six additional genotypes with known resistant reaction to crown rot were used as control in this study (Table 1). One week after transplanting pregerminated seeds, each seedling was inoculated with $1 \mathrm{ml}$ of spore suspension of $F$. culmorum at a rate of $1 \times 10^{6}$ spore per $\mathrm{ml}$ of water. To enhance infection; inoculated seedlings were covered with plastic tent and incubated at $75 \%$ of relative humidity and watered from bottom and kept in the dark for $48 \mathrm{~h}$ before removing the plastic cover and left to grow under the growth room conditions for 49-56 days with $16 \mathrm{~h}$ of artificial photoperiod and at $23{ }^{\circ} \mathrm{C}$ with relative humidity of $65 \pm 5 \%$ as per Mitter et al. (2006). Each treatment was replicated 5 times and tubes were placed in a completely randomised block design. Trials were repeated once for data validation.

\section{Adult Plant Screening (Greenhouse and Field)}

A single wheat seed was sown in each plastic tube (Stuewe and Sons, Corvallis, OR) $(21 \mathrm{~cm}$ height $x 3.8$ $\mathrm{cm}$ diam.) filled with the same potting mixture as mentioned above and was inoculated with $0.25 \mathrm{~g}$ of wheat bran F. culmorum consisted of about $5 \times 10^{5}$ spore per $\mathrm{ml}$. Wheat bran were soaked in $1 \mathrm{ml}$ water to estimate relative spore concentration by using a hemocytometer. The plants were left to grow under the greenhouse from October to June (winter wheat growing season) and harvested at maturity as lined with natural field conditions. In order to enhance disease symptoms, water was reduced near heading stage to stimulate post anthesis drought stress. The method used in this test was similar to that described by Wallwork et al. (2004). Plants were watered whenever needed. Each treatment was replicated 6 times and placed in a completely randomised block design. For field assay, wheat genotypes (141 genotype) plus the breedinglines/varieties (6 genotypes) were planted at ILCI private agricultural research institute in Kırsehir, Turkey in 2012. For each genotype, $5 \mathrm{~g}$ seeds were hand planted in row of $1 \mathrm{~m}$ long and replicated 3 times in a completely randomised block design. In 2013, a set of 69 selected genotypes based on their performance in 2012 screening and showed promising resistant reaction were re-evaluated under the same field conditions for data validation. At harvest time, up to 20 tillers of each genotype (replicate) was randomly selected, peeled, and assessed for F. culmorum disease symptoms as per Erginbas-Orakci et al. (2012; 2016).

\section{Statistical Analysis}

Plants were harvested and assessed based on the browning/rotting percentage on the crown which describes the stem ( $1 \mathrm{~cm}$ above soil level) according to the modified 1-5 scale: $1=1-9 \%$ Resistant $(R), 2=10-$ 29\% Moderately Resistant (MR), 3= 30-69\% Moderately Susceptible (MS), 4=70-89\% Susceptible (S), 5= 90-100\% Highly Susceptible (HS) (Wildermuth and McNamara 1994; Erginbas-Orakci et al., 2016). The data were analyzed according to standart analysis of variance. Significant differences between the 
Erginbaş Orakci et al., Determination of Resistance in Winter Wheat Genotypes to The Dryland Root Rots caused by Fusarium culmorum in Turkey

genotype was performed based on the Least Significant Difference (LSD). JMP10 statistical package program was used for tests.

\section{RESULT}

The tested genotype showed disease severity ranged between $1 \%$ and $89 \%$ (Wildermuth and McNamara 1994). The genotypes were categorized into 5 groups based on their reaction ranging from Resistant (R) to Highly Susceptible (HS). The breedinglines/varieties used in the study gave the expected reactions against the disease under the different screened environments. The tetraploid Kiziltan 91 used in this study showed higher susceptible expression than the hexaploid Seri 82. Out of the 141 genotype screened in 2012 a subset of 69 promising genotype were selected based on their resistant reaction to $F$. culmorum under the three different screening environments (growth room, greenhouse and field) in the 1st run. The results of the validation study resulted in 16 genotype with same or better resistant reaction to the foot rot disease when compared to the breedinglines/varieties used in the study (Table 2). Two of the 16 genotype gave resistant reaction to crown rot at both seedling and adult stages in particularly PATWIN YR5 and TAST/SPRW//ZAR/5/YUANDONG3/4/PPB8-68/CHRC /3/PYN//TAM101/AMIGO and considered moderately resistance against Fusarium culmorum. Based on the grouping genotype screened for adult plant resistance (APR) in both greenhouse and field resulted in $2.8 \%$ MR-R, 59.5\% MS, and $37.5 \% \mathrm{~S}-\mathrm{HS}$. While genotype screened for seedling resistant gave $11.3 \%$ R-MR, 54.6\% MS, and 34\% S-HS. The highest frequencies of resistant reaction to $F$. culmorum were obtained from those genotype originated from Romania, Turkey, USA, IWWIP, Mexico - IWWIP (Table 2). Genotypes KS82142/PASTOR, DEFENSE, EXCALIBUR/WBLL1, PATWIN-YR5, ALAMOOT/4/KAL/ $\mathrm{BB} / \mathrm{CJ} / 3 / \mathrm{HORK}$ can be considered as valuable sources for foot rot ( $F$. culmorum). The set was also screened against other soil borne disease cereal cyst nematode (Heterodera filipjevi) as well as main foliar diseases caused by the 3 rusts species (Table 3). The performance of selected resistant genotypes and their reaction for multiple diseases (CCN and Rusts) are given in Table 3 (Rust data is obtained from IWWIP). The data has indicated that entry $26,62,65,67,73$, and 111 which were good for crown rot were also good for all rust diseases tested (stripe, leaf and stem rust). Agronomy and grain quality parameters for selected lines were performed on those genotypes and will be of high importance to the breeding programs to pyramide the different traits in a high yielding widely cultivated varieties (Table 4; Data is obtained from IWWIP).

\section{DISCUSSION}

To date a wide range and diverse germplasm from around the globe obtained from CIMMYT-Mexico and IWWIP (International Winter Wheat Improvement Program) has been phenotypically screened in terms of their resistance to Fusarium crown rot (ErginbasOrakci et al., 2013a). Wheat genotype resistant to crown rot is limited, therefore, developing and/or identifying a new genotype with acceptable level of resistance will greatly benefit wheat producers 'farmers'. Implementing the resistant germplasm with other cultural practices such as crop rotation and other Integrated Pest Managemengt (IPM) will ultimately reduce the damage and increase the grain yield (Erginbas-Orakci et al., 2010). The damage on cereals caused by soil borne pathogens especially the Fusarium genus are known in wheat producing areas globally (Smiley et al., 2005; Chakraborty et al., 2010). The present investigation demonstrated that $F$. culmorum is highly agressive on wheat genotypes. Using resistant genotypes of high yielding potential is the most effective and economical way to control soil borne pathogens, especially under drought areas where cereals are cultivated and monoculture cropping systems exist (Erginbas-Orakci et al., 2013b). Efforts has been made by pathologists around the globe to find Quantitative Trait Loci (QTLs) against the crown rot. However, only few sources were identified with partial resistance (Wallwork et al., 2004; Collard et al., 2005; Ma et al., 2009; Li et al., 2010). The results of this study clearly show high variation in their resistance reaction between and/or among the tested genotypes. All genotypes assessed for crown symptoms at seedling stage for seedling resistance in growth room, at adult plant resistance under greenhouse and field conditions showed various reactions to the pathogen $F$. culmorum. The genotypes were ranked according to the browning/rotting severity on the crown and were compared to the controls used in this study. The genotypes which showed consistency in disease ratings both at seedling and adult stages over the 2 growing season were considered reliable and promising lines. As reported by Smiley and Yan (2009), a high degree of variation in response to crown rot disease over years and found it difficult to establish reliable tolerance standards in wheat genotypes. Therefore, the slightly variation between the lines and controls (which seen more adapted) in our study might be due to the uneven 
Table 2. Mean crown rotting data of 17 promising winter wheat genotypes including controls assessed under growth room, greenhouse and field conditions at 2 consecutive years $(2012 / 13)$.

Çizelge 2. Büyütme odası, sera ve tarla koşullarında ümitvar 17 kışlık buğday genotipi ile kontrol hat/çeşitlerin kök boğazı çürüklüğüne ait 2012 -2013 yılı ortalama verileri.

\begin{tabular}{|c|c|c|c|c|c|c|c|c|c|c|}
\hline OE & CNAME & TK ACC & OC & Field & Greenhouse & $\begin{array}{l}\text { Growth- } \\
\text { room }\end{array}$ & Field & Greenhouse & $\begin{array}{l}\text { Growth } \\
\text { room }\end{array}$ & $\begin{array}{l}\text { Seedling Stage } \\
\text { Resistance: SSR, } \\
\text { Adult Stage } \\
\text { Resistance: ASR }\end{array}$ \\
\hline 26 & KS82142/PASTOR & 050117 & $\begin{array}{l}\text { United States of America- } \\
\text { IWWIP }\end{array}$ & & 2.8 & 2.0 & 2.0 & 2.0 & 2.0 & SSR \\
\hline 38 & DEFENSE & 980221 & France & 2.5 & 3.0 & 2.0 & 3.0 & 2.7 & 2.4 & SSR \\
\hline 47 & F02106G2-1FZ101 & 110613 & Romania & 2.5 & 2.7 & 1.0 & 3.0 & 3.3 & 2.0 & SSR \\
\hline 49 & ES85-19/V-763-254/3/RSK/NAC//CTK/VEE & 101320 & Turkey & 2.0 & 3.7 & 2.0 & 3.0 & 1.3 & 1.8 & SSR \\
\hline 57 & EXCALIBUR/WBLL1 & 100037 & Mexico & 2.0 & 2.7 & 4.0 & 2.0 & 1.8 & 3.0 & ASR \\
\hline 62 & ABI 86*3414/X84W063-9-39-2//KARL92 & 020486 & United States of America & 3.0 & 2.5 & 2.2 & 2.0 & 1.5 & 1.5 & SSR \\
\hline 65 & 85ZHONG33/ZLATOSTRUI//PLK70/LIRA & 000022 & IWWIP & 1.0 & 2.0 & 2.0 & 4.0 & 3.5 & 2.0 & SSR \\
\hline 67 & BONITO-44 & 010268 & Mexico-IWWIP & 1.5 & 2.8 & 1.0 & & 2.2 & 2.5 & ASR \\
\hline 68 & $\begin{array}{l}\text { SABALAN//KRC66/SERI/5/JUP/4/CLLF/3/II14- } \\
\text { 53/ODIN//CI134431/SEL6425/WA00477 }\end{array}$ & 030084 & IWWIP & 2.5 & 2.7 & 2.0 & 2.0 & 2.3 & 2.3 & SSR \\
\hline 69 & PATWIN YR5 & 100894 & United States of America & 2.0 & 2.2 & 2.0 & . & 2.3 & 2.0 & ASR-SSR \\
\hline 73 & ALAMOOT/4/KAL/BB//CJ/3/HORK & 090859 & Iran-Karadj & 2.5 & 2.5 & 2.0 & 4.0 & 1.3 & 2.2 & SSR \\
\hline 78 & $\begin{array}{l}\text { W95-091 (=KS85-663-8-9//WI81- } \\
\text { 133/THUNDERBIRD)/AKRON }\end{array}$ & 101038 & United States of America & 3.0 & 3.7 & 2.0 & 4.0 & 2.2 & 2.4 & SSR \\
\hline 95 & OWL//OMBUL/ALAMO & 120001 & Iran-Karadj & 3.0 & 3.3 & 1.0 & 2.0 & 1.5 & 1.4 & SSR \\
\hline 111 & $00 * 0100-51$ & 101287 & United States of America & 2.5 & 3.5 & 2.0 & 4.0 & 2.5 & 2.3 & SSR \\
\hline 113 & TX98D3447/TX99D4657 & 100010 & Unites States of America & 3.0 & 2.5 & 2.0 & 2.0 & 2.5 & 1.7 & SSR \\
\hline 120 & $\begin{array}{l}\text { TAST/SPRW//ZAR/5/YUANDONG 3/4/PPB8- } \\
\text { 68/CHRC/3/PYN//TAM101/AMIGO }\end{array}$ & 060026 & IWWIP & 2.0 & 2.8 & 2.0 & 2.0 & 1.0 & 2.4 & ASR-SSR \\
\hline \multirow[t]{9}{*}{124} & $\begin{array}{l}\text { 4WON-IR- } \\
\text { 257/5/YMH/HYS//HYS/TUR3055/3/DGA/4/VPM/ } \\
\text { MOS }\end{array}$ & 090433 & IWWIP & 3.0 & 3.7 & 2.0 & 1.0 & 1.2 & 1.8 & SSR \\
\hline & 249 - control & & Australia & 2.2 & 2.3 & 2.2 & 2.2 & 2.3 & 2.4 & \\
\hline & Altay 2000-control & & Turkey & 2.5 & 2.8 & 2.4 & 2.4 & 2.3 & 2.4 & \\
\hline & Sonmez - control & & Turkey & 2.5 & 2.5 & 2.4 & 2.5 & 2.4 & 2.4 & \\
\hline & Sunco-control & & Australia & 3.0 & 2.0 & 3.0 & 2.8 & 2.2 & 3.0 & \\
\hline & Seri 82 -control & & Mexico & 3.5 & 3.4 & 3.6 & 3.5 & 3.2 & 4.0 & \\
\hline & Kiziltan 91 - control & & Turkey & 3.0 & 3.5 & 4.4 & 3.4 & 3.3 & 4.4 & \\
\hline & LSD & & & 0.27 & 0.51 & 0.27 & 0.13 & 0.50 & 0.62 & \\
\hline & Prob & & & $\begin{array}{c}<.00 \\
01\end{array}$ & $<.0001$ & $<.0001$ & $\begin{array}{c}<.000 \\
1\end{array}$ & $<.0001$ & $<.0001$ & \\
\hline
\end{tabular}


Table 3. The best performed winter wheat genotypes against to the root rot pathogen Fusarium culmorum supported by data from leaf disease rust (including avaliable resistance gene data) and from other soil borne disease ceral cyst nematodes under field and/or controlled conditions in Turkey.

Çizelge 3. Kök çürüklügü etmeni Fusarium culmorum' a karşı en iyi performans gösteren kışlık buğday genotipleri ve Türkiye'de tarla ve/veya kontrollü koşullar altında diğer toprak kökenli hastalık etmeni tahıl kist nematodu ve yaprak pas hastalıkları' na karşı (mevcut dayanıklılı geni verileri) dayanıklılı reaksiyonları.

\begin{tabular}{|c|c|c|c|c|c|c|c|c|c|c|c|}
\hline $\mathrm{OE}$ & Cross name & $\begin{array}{l}\text { TK } \\
\text { ACC }\end{array}$ & OC & Stripe Rust & Adult Plant R & $\begin{array}{l}\text { ponse }(J \\
\text { eaf Rust } \\
\text { Rust }\end{array}$ & e 2012) & Stem & \multirow[t]{2}{*}{$\begin{array}{l}\text { Stem } \\
\text { Rust- } \\
\text { Gene }\end{array}$} & $\begin{array}{l}\text { Leaf } \\
\text { rust- } \\
\text { Gene }\end{array}$ & $\begin{array}{c}\text { CCN } \\
\text { Heterode } \\
\text { a Filipjev } \\
\text { Reaction }\end{array}$ \\
\hline & & & & Haymana & Adapazarı & Izmir & Haymana & Izmir & & & \\
\hline 26 & KS82142/PASTOR & 050117 & $\begin{array}{l}\text { United States of America } \\
\text {-Oregon. Turkey Cimmyt } \\
\text { Icarda }\end{array}$ & TMS & 0 & TMS & $5 \mathrm{MR}$ & $5 \mathrm{MR}$ & $\mathrm{Sr} 2$ & & MR \\
\hline 38 & DEFENSE & 980221 & France & 0 & 0 & TMS & $80 \mathrm{~S}$ & $40 \mathrm{~S}$ & HET & & MR \\
\hline 47 & F02106G2-1FZ101 & 110613 & Romania & 0 & 0 & $10 \mathrm{MS}$ & $30 \mathrm{MSS}$ & $20 \mathrm{~S}$ & & & MS \\
\hline 49 & $\begin{array}{l}\text { ES85-19/V-763- } \\
\text { 254/3/RSK/NAC//CTK/VEE }\end{array}$ & 101320 & Turkey & TMS & 0 & $5 \mathrm{MS}$ & $40 \mathrm{~S}$ & $30 \mathrm{~s}$ & Sr2 & & MS \\
\hline 57 & EXCALIBUR/WBLL1 & 100037 & Mexico & $\mathrm{T}-20 \mathrm{MS} / 0$ & TMS & TMS & $70 \mathrm{~S}$ & $20 \mathrm{MS}$ & $\begin{array}{l}\text { Sr2. } \\
\text { Sr24 }\end{array}$ & & MR \\
\hline 62 & ABI 86*3414/X84W063-9-39-2//KARL92 & 020486 & $\begin{array}{l}\text { United States of America } \\
\text {-Kansas }\end{array}$ & TMS & 0 & 0 & $0 / 10 \mathrm{~S}$ & $5 \mathrm{MS}$ & $\mathrm{Sr} 2$ & & MS \\
\hline 65 & 85ZHONG33/ZLATOSTRUI//PLK70/LIRA & 000022 & Turkey-Cimmyt-Icarda & TMS & 0 & 0 & 0 & TMR & $\begin{array}{l}\text { Sr2. } \\
\text { Sr24 }\end{array}$ & & MS \\
\hline 67 & BONITO-44 & 010268 & $\begin{array}{l}\text { Mexico- Turkey-Cimmyt- } \\
\text { Icarda }\end{array}$ & 0 & TMR & TMR & $10 \mathrm{MSS}$ & $10 \mathrm{~S}$ & $\mathrm{Sr} 2$ & Lr34 & MS \\
\hline 68 & $\begin{array}{l}\text { SABALAN//KRC66/SERI/5/JUP/4/CLLF/3 } \\
\text { /I114- } \\
\text { 53/ODIN//CI134431/SEL6425/WA00477 }\end{array}$ & 030084 & Turkey-Cimmyt-Icarda & 70SMS/0 & $10 \mathrm{MR}$ & $5 \mathrm{MS}$ & $20 \mathrm{MSS}$ & TMS & Sr2 & & MS \\
\hline 69 & PATWIN YR5 & 100894 & United States of America & 0 & TMR & 0 & 0 & TMS & HET & & MR \\
\hline 73 & ALAMOOT/4/KAL/BB//CJ/3/HORK & 090859 & Iran-Karadj & 0 & $5 \mathrm{MR}$ & $\begin{array}{l}\text { TMS- } \\
10 \mathrm{MS}\end{array}$ & $20 \mathrm{MSS}$ & 0 & $\mathrm{Sr} 2$ & & MR \\
\hline 78 & $\begin{array}{l}\text { W95-091 (=KS85-663-8-9//WI81- } \\
\text { 133/THUNDERBIRD)/AKRON }\end{array}$ & 101038 & & 0 & 0 & 0 & $60 \mathrm{~S}$ & $10 \mathrm{MS}$ & Sr2 & & MS \\
\hline 95 & OWL//OMBUL/ALAMO & 120001 & Iran-Karadj & 0 & 20MSS & $70 \mathrm{~S}$ & $90 \mathrm{~S}$ & $10 \mathrm{~s}$ & & & MS \\
\hline 111 & $00 * 0100-51$ & 101287 & US-AGRIPRO & 0 & $5 \mathrm{MR}$ & 0 & 0 & TMS & & & \\
\hline 113 & TX98D3447/TX99D4657 & 100010 & US-ARS-NC & $100 \mathrm{~S}$ & 0 & 0 & $20 \mathrm{MR}$ & 0 & $\mathrm{Sr} 2$ & & - \\
\hline 120 & $\begin{array}{l}\text { TAST/SPRW//ZAR/5/YUANDONG } \\
\text { 3/4/PPB8- } \\
\text { 68/CHRC/3/PYN//TAM101/AMIGO }\end{array}$ & 060026 & Turkey-Cimmyt-Icarda & 0 & $20 \mathrm{MSS}$ & $10 \mathrm{MS}$ & 0 & $10 \mathrm{MS}$ & $\mathrm{Sr} 2$ & Lr34 & - \\
\hline
\end{tabular}


Table 3. Continue.

Çizelge 3. Devamı.

\begin{tabular}{|c|c|c|c|c|c|c|c|c|c|c|c|}
\hline$\frac{O E}{124}$ & Cross name & TK ACC & OC & Stripe Rust & \multicolumn{3}{|c|}{$\begin{array}{l}\text { Adult Plant Response (June 2012) } \\
\text { Leaf Rust }\end{array}$} & \multirow{2}{*}{$\begin{array}{r}\text { Stem Rust } \\
10 \mathrm{MS}\end{array}$} & $\begin{array}{r}\begin{array}{r}\text { Stem } \\
\text { Rust- } \\
\text { Gene }\end{array} \\
\text { Sr2 }\end{array}$ & $\begin{array}{l}\text { Leaf } \\
\text { rust- } \\
\text { Gene } \\
\end{array}$ & $\begin{array}{c}\text { CCN } \\
\text { Heteroder } \\
\text { a Filipjevi }\end{array}$ \\
\hline 124 & $\begin{array}{l}\text { 4WON-IR- } \\
\text { 257/5/YMH/HYS//HYS/TUR3055/3/DGA } \\
\text { /4/VPM/MOS }\end{array}$ & 090433 & Turkey-Cimmyt-Icarda & 0 & TMS & TMR & $60 \mathrm{~S}$ & & & & - \\
\hline & Altay 2000-control & 010627 & Turkey & 0 & $5 \mathrm{MS}$ & $10 \mathrm{MS}$ & $10 \mathrm{~S}$ & $50 \mathrm{~s}$ & $\mathrm{Sr} 2$ & & $\mathrm{~s}$ \\
\hline & Bezostaja-control & 950189 & Russia & $60 \mathrm{MSS}$ & $30 \mathrm{MSS}$ & TMS & $60 \mathrm{~S}$ & $100 \mathrm{~s}$ & HET & Lr34 & $\mathrm{s}$ \\
\hline & Bayraktar-control & 010571 & Turkey & 0 & TMR & TMS & 0 & $5 \mathrm{~S}$ & $\mathrm{Sr} 2$ & & HS \\
\hline & Karahan-control & 920007 & Turkey & $70 \mathrm{MS}$ & $10 \mathrm{MS}$ & $10 \mathrm{MS}$ & 10MSS/0 & $\begin{array}{c}10 \\
\text { MR/MS }\end{array}$ & $\mathrm{Sr} 2$ & & MS \\
\hline & Mufitbey-control & 020211 & Turkey Cimmyt Icarda & 0 & TMR & TMS & $50 \mathrm{~S}$ & $50 \mathrm{~s}$ & $\mathrm{Sr} 2$ & & HS \\
\hline
\end{tabular}

OE: Original entry.TK: Turkey. ACC: Accession. OC: Origin country. Adult plant severity and infection type asssed according to the Cobb's scale (Peterson et al.,1948) for rust diseases;

T: Trace severity. MR: Moderately resistant. MS: Moderately susceptible. S: Susceptible. MSS:Moderately susceptible to susceptible.S:susceptible. HS: highly susceptible. CCN: Cereal Cyst Nematode:

1 to 5 scale (Dababat et al., 2014) was used to group the genotypes according to their reaction against Heterodera filipjevi. 
Table 4. The best performed winter wheat genotype against to the root rot pathogen Fusarium culmorum supported by data from agronomy and quality parameters.

Çizelge 4. Kök çürüklügü etmeni Fusarium culmorum' a karşı en iyi performans gösteren kışlık buğday genotipleri ve agronomi ve kalite özellikleri.

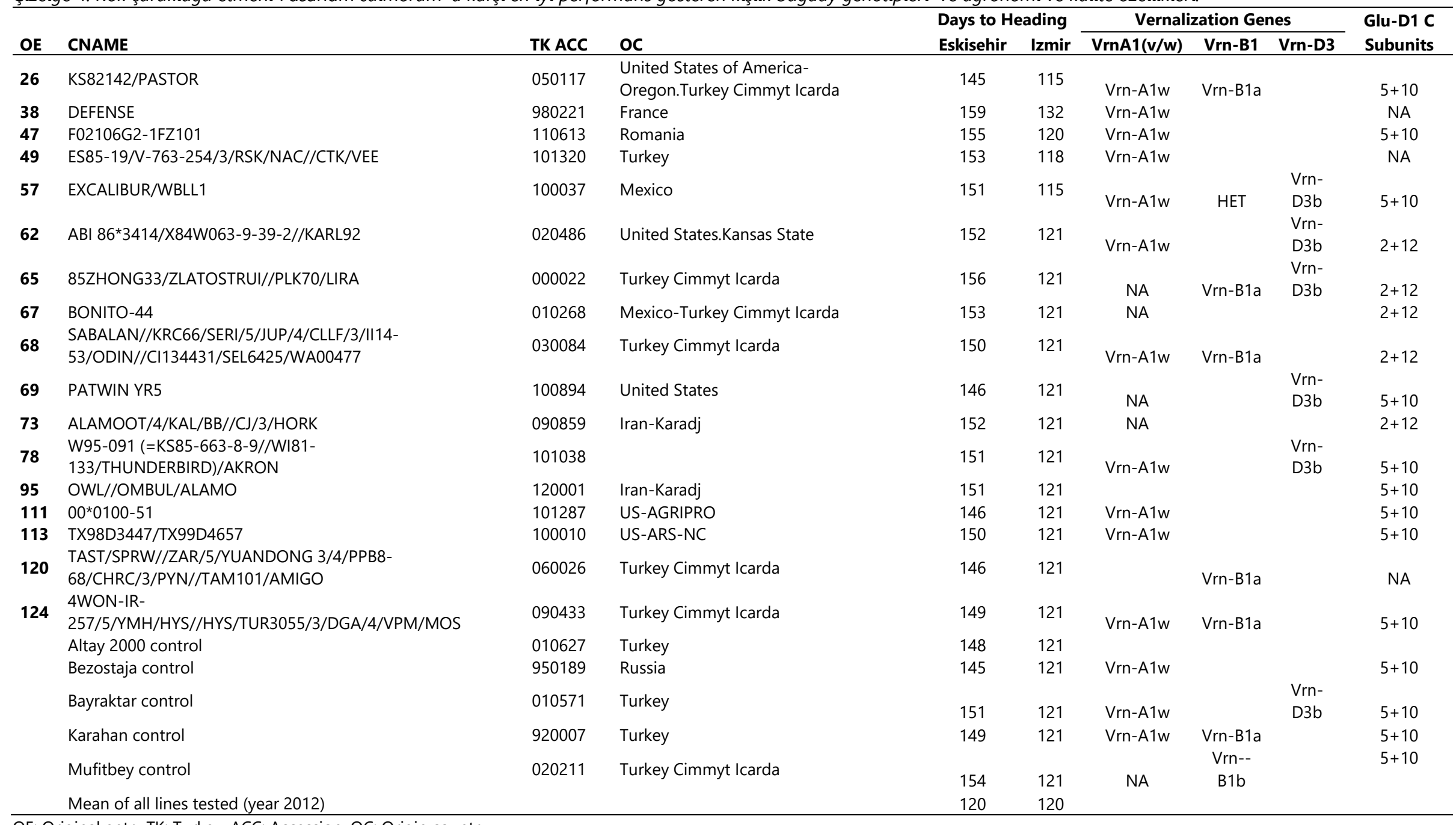

OE: Original entry.TK: Turkey. ACC: Accession. OC: Origin country. 
inoculation and environmental factors. Symptoms were more distinct under the greenhouse when compared to the field as this was contributed to the optimal environment for the disease to develop under the greenhouse. Also sterilized soil was used for the greenhouse trials versus field soil with its complex ecosystem which might affect disease development. Severity of the disease can be assessed in many ways depending on the objectives of the screening whether it is aiming to screen for adult plant or seedling resistance. Use of seedlings will speed the selection of resistant progeny in wheat breeding programs where resistance to the disease is an objective (Wildermuth and McNamara 1994).

Resistance has been found more than one soil borne pathogens enabling the breeders to use these genotypes for soilborne disease complex. In this study, 17 wheat genotypes were found to be MR to the crown rot and well adapted to the Turkish dryland conditions and therefore are recommended for crosses in the breeding programs.

\section{ACKNOWLEDGEMENTS}

The authors would like to thank the Turkish Ministry of Agriculture and Livestock (TMFAL) especially Transitional Zone Agriculture Research Institute of Eskisehir, Turkey for providing the technical support and the International Winter Wheat Improvement Program (IWWIP) for providing additional data on the screened materials.

\section{REFERENCES}

Akgül DS., 2008. The status of the root, crown and foot rot disease in wheat growing areas of Cukurova region, determination of cultivar reactions, effect of some fertilization and fungicide applications on disease development, PhD Thesis, Cukurova University Institute of Science, Adana.

Aktas H., Kinaci E., Yildirim AF., Sayin L and Kural A., 1999. Determination of root and foot rot pathogens which are problems in Konya province and research and solution. Central Anatolia Cereal Agriculture Problems and Solutions Symposium, 8-11 Haziran, Konya.

Alexandratos N and Bruinsma J., 2012. World agriculture towards 2030/2050: the 2012 Revision. FAO, Agricultural Development Economics Division, ESA Working Paper No. 12-03. www.fao.org/economic/esa. [Access: April 9, 2018].

Bagci SA., Hekimhan H., Mergoum M., Aktas H., Taner S., Tulukcu E and Ekiz H, 2001. Effects of foot and root rot pathogens on yields of some cereal genotypes and determination of resistance sources. $4^{\text {th }}$ Field crops Congress, 17-21 September, Tekirdağ, Turkey.
Benli B., Pala M., Stockle C and Oweis T., 2007. Assessment of winter wheat production under early sowing with supplemental irrigation in a cold highland environment using CropSyst simulation model. Agricultural Water Management, 93: 45-53.

Bentley AR., Tunali B., Nicol JM., Burgess LW and Summerell BA., 2006. A survey of Fusarium species associated with wheat and grass stem bases in northern Turkey. Sydowia, 58: 163-177.

Bovill WD., Ma W., Ritter K., Collard BCY., Davis M., Wildermuth GB and Sutherland MW., 2006. Identification of novel QTL for resistance to crown rot in the doubled haploid wheat population 'W21MMT70' x 'Mendos'. Plant Breeding, 125: 538-543.

Braun HJ, Zencirci N, Altay F, Atli A, Muzaffer A, Esser V, Kambertay $M$ and TS Payne, 2001. Turkish wheat pool. The world wheat book: A history of wheat breeding (Eds. AP Bonjean and Angus WJ), Lavoisier Press, pp. 851-879.

Braun HJ, Atlin G and Payne T. 2010. Multi-location testing as a tool to identify plant response to global climate change. Climate Change and Crop Production (Ed. Reynolds MP), CABI Press, pp. 115-138.

Burgess LW., Backhouse D., Summerell BA and Swan J., 2001. Crown Rot of Wheat. Fusarium (Eds. Summerell BA., Leslie JF., Backhouse D., Bryden WL and Burgess LW), Fusarium Paul E Nelson Memorial Symposium. APS Press, pp. 271-294.

Burgess LW., Bentley AR., Purs GS., Wildermuth GB and Dodman RL., 2012. Crown rot of wheat and barley caused by Fusarium Pseudograminearum: A stress-related disease. First International Crown Rot workshop for wheat Improvement, 22-23 October, Narrabri, Ew South Wales, Australia.

Chakraborty S., Obanor F., Westecott R and Abeywickrama K., 2010. Wheat crown rot pathogens Fusarium graminearum and F. pseudograminearum lack specialization. The American Phytopathological Society, 100: 1057-165.

Chekali S., Gargouri S., Rezgui M and Paulitz T., and Nasraoui B. (2016). Impacts of previous crops on Fusarium foot and root rot, and on yields of durum wheat in north West Tunisia. Phytopathologia Mediterranea, 55: 253-261.

Cook RJ., 1980. Fusarium foot rot of wheat and its control in the Pacific Northwest. Plant Disease, 64: 1061-1066.

Collard BCY., Grams RA., Bovill CD., Percy CD., Jolley R., Lehmensiek A., Wildermuth G and Sutherland MW., 2005. Development of molecular markers for crown rot resistance in wheat: mapping of QTL for seedling resistance in a '2-49' x 'Janz' population. Plant Breeding, 124: $532-537$.

Erginbas-Orakci G., Yamac M., Amoroso MJ and Cuozzo SA., 2010. Selection of antagonistic actinomycete isolates as 
Erginbaş Orakci et al., Determination of Resistance in Winter Wheat Genotypes to The Dryland Root Rots caused by Fusarium culmorum in Turkey

biocontrol agents against root-rot fungi. Fresenius Environmetal Bulletin, 19(3): 417-424.

Erginbas-Orakci G., Dababat AA., Nicol JM and Bolat N., 2012. Screening methods to identify and validate moderately resistant wheat germplasm against the dryland crown rot (Fusarium culmorum) used by CIMMYT-Turkey under field and controlled conditions. First International Crown Rot workshop for Wheat Improvement, 22-23 October, Narrabri, New South Wales, Australia.

Erginbas-Orakci G., Dababat AA., Morgounov A and Braun HJ., 2013a. Identifying new sources of resistant in wheat germplasms for dryland crown rot caused by Fusarium culmorum. Acta Phytopathologica Sinica, 43: 512-513.

Erginbas-Orakci G., Dababat AA., Morgounov A and Braun HJ., 2013b. The dryland crown rot disease: status of control options. Technical Innovation Brief. No:19 http://www.spipm.cgiar.org/c/document_library/get_file ?p_I_id = 17830\&folderld =18484\&name=DLFE-5843.pdf. [Access: January 10, 2018].

Erginbas-Orakci G., Poole G. Nicol JM., Paulitz T, Dababat AA and Campbell K., 2016. Assessment of inoculation methods to identify resistance to Fusarium crown rot in wheat. Journal of Plant Diseases and Protection, 123: 1927.

FAO 2018. www.fao.org/worldfoodsituation/csdb/en/ [Access: April 9, 2018].

Hekimhan H., Bagci SA., Nicol J., Arisoy RZ and Taner S., 2004. Dryland Root Rot : a major threat to winter cereal production under sub-optimal growing conditions. 4th International Crop Science Congress, 27 September-01 October, Brisbane, Australia.

Klein TA., Burgess W and Ellison FW., 1991. The incidence and spatial patterns of wheat plants infected by Fusarium graminearum Group 1 and the effect of crown rot on yield. Australian Journal Agriculture Research, 42: 399407.

Li HB., Xie GQ., Ma J., Liu GR., Wen SM., Ban T., Chakraborty $S$ and Liu CJ., 2010. Genetic relationships between resistances to Fusarium head blight and crown rot in bread wheat (Triticum aestivum L.). Theoretical and Applied Genetics, 121: 941-950.

Li HB., Zhou M.X., Liu CJ., 2012. Development and validation of markers closely linked to crown rot resistance in wheat and barley. Molecular Plant Breeding, 3: 80-90.
Ma J., Li H., Zhang C., Yang X., Liu Y., Yan G and Liu C., 2009. Identification and validation of a major QTL conferring crown rot resistance in hexaploid wheat. Theoritical Applied Genetics, 6: 1119-1128.

Mitter V., Zhang MC., Liu C.J., Ghosh R., Ghosh M and Chakraborty SA., 2006. High-throughput bioassay to detect crown rot resistance in wheat germplasm. Plant Pathology, 55: 433-441.

Nicol J., Bagci S.A., Hekimhan H., Tunali B., Bolat N., Braun HJ and Trethowan R., 2004. Strategy for the identification and breeding of resistance to Dryland root rot complex for international spring and winter wheat breeding programs. 4th International Crop Science Congress, 26 Septemver-01 October, Brisbane, Australia.

Nicholson P., Simpson DR., Weston G., Rezanoor HN., Lees AK., Parry DW and Oyce DE., 1998. Detection and quantification of Fusarium culmorum and Fusarium graminearum in cereals using PCR assays. Physiological and Molecular Plant Pathology, 53: 17-37.

Shikur ES., Sharma-Poudyal D., Paulitz TC., Erginbas-Orakci G., Karakaya A and Dababat AA., 2017. Identity and pathogenicity of Fusarium species associated with crown rot on wheat (Triticum spp.) in Turkey. European Journal of Plant Pathology, 150(2): 387-399.

Smiley RW., Gourlie JA., Easley SA, Patterson LM and Whittaker RG., 2005. Crop damage estimates for crown rot of wheat and barley in the Pacific Northwest. Plant Disease, 89: 595-604.

Smiley RW and Yan H., 2009. Variability of FCR tolerances among cultivars of spring and winter wheat. Plant Disease, 93: 954-961.

Statler GD and Darlington LC., 1972. Resistance of hard red spring wheat and durum wheat to seedling blight and crown rot. Plant Disease Reporter, 56: 788-791.

Tunali B., Nicol JM., Hodson D., Uçkun Z., Büyük O., Erdurmuş D., Hekimhan H., Aktaş H., Akbudak MA and Bağcı, SA., 2008. Root and crown rot fungi associated with spring, facultative, and winter wheat in Turkey. Plant Disease, 92: 1299-1306.

Wallwork H., Butt M., Cheong JPE., Williams KJ., 2004. Resistance to crown rot in wheat identified through an improved method for screening adult plants. Australian Plant Pathology, 33: 1-7.

Wildermuth GB and McNamara RB., 1994. Testing wheat seedlings for resistance to crown rot caused by Fusarium graminearum Group 1. Plant Disease, 78: 949-953. 